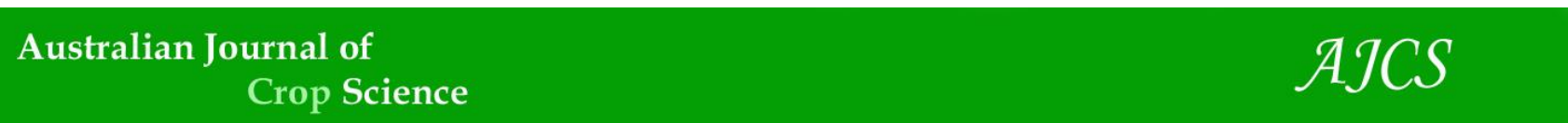

AJCS 15(05):634-637 (2021)

ISSN:1835-2707

doi: 10.21475/ajcs.21.15.05.p2837

\title{
Selection of potato clones derived from seed tubers for nutritional efficiency to phosphorus
}

\section{Darlene Sausen ${ }^{1 *}$, Ivan Ricardo Carvalho ${ }^{2}$, Miriam da Silva Tavares ${ }^{3}$, Márcio Renan Weber Schorr ${ }^{4}$, Raíssa Schwalbert ${ }^{1}$, Camila Peligrinotti Tarouco ${ }^{1}$, Ritieli Baptista Mambrin ${ }^{5}$, Anderson Cesar Ramos Marques ${ }^{1}$, Francine Lautenchleger ${ }^{6}$, Fernando Teixeira Nicosolo ${ }^{1}$}

\author{
${ }^{1}$ Federal University of Santa Maria, Santa Maria, RS, Brazil \\ ${ }^{2}$ Northwest Regional University of the State of Rio Grande Do Sul, ljuí, RS, Brazil \\ ${ }^{3}$ Goiás State University, Posse, GO, Brazil \\ ${ }^{4}$ National Supply Company, Porto Alegre, RS, Brazil \\ ${ }^{5}$ Riograndense Higher Education Center, Marau, RS, Brazil \\ ${ }^{6}$ University of the Midwest, Guarapuava, PR, Brazil
}

\section{*Corresponding author: darlene_sn@yahoo.com.br}

\begin{abstract}
To develop agricultural systems that produce more food with limited availability of phosphorus $(\mathrm{P})$ it is necessary to explore the genetic variability of plants and select potato clones that are more efficient at $P$ use. The objective of this study was to evaluate the performance of four potato clones for $\mathrm{P}$ nutritional efficiency in closed off-soil growing system using native soil as substrate. Therefore, seed tubers from the four potato clones (Asterix, Atlantic, SMIC 148-A and SMINIA 793101-3) were planted in plastic pots with native soil as a substrate, where the treatments consisted of two levels of $P\left(0.025\right.$ and $\left.0.11 \mathrm{~g} \mathrm{~kg}^{-1} \mathrm{KH}_{2} \mathrm{PO}_{4}\right)$. 52 days after planting, the concentration of $\mathrm{P}$ in the shoot, the shoot and the total dry mass, the rooting efficiency, $\mathrm{P}$ absorption, $\mathrm{P}$ translocation and use of $\mathrm{P}$ were evaluated. SMIC $148-\mathrm{A}$ is the clone that most concentrates $\mathrm{P}$ in the shoot and that produces more total dry mass under low $\mathrm{P}$, while SMINIA 793101-3 is the most efficient clone in the absorption and translocation of $\mathrm{P}$ under low nutrient level, however, the Asterix and Atlantic clones showed greater efficiency in the use of $P$.
\end{abstract}

\section{Introduction}

The increase in population and food consumption in the coming years will bring challenges for agriculture to be overcome in order to maintain or even increase crop productivity using fewer natural resources (Godfray et al., 2010; Tester and Langridge, 2010). Food production requires application of phosphorus (P), nitrogen and potassium in the soil to maintain high yields, with $P$ having no substitute in food production and is one of the least available nutrients in soils for agricultural production (Godfray et al., 2010). Thus, the use of phosphate fertilizers to produce food follows the line of population growth. Ensuring the long-term availability and accessibility of $P$ is fundamental to global food security (Cordel et al., 2009), since the reserves of phosphate rocks for the production of fertilizers are finite and the agricultural area is limited (Godfray et al., 2010).

The consumption of potato (Solanum tuberosum L.) is large in the world because it is a highly energetic vegetable and an important source of vitamins and minerals (Dale and Mackay, 1994). With regard to the productive potential of potato growing, it is observed that it is, on average, twice as large as the growing of a grain crop (Rhoads, 2003). The potato plant produces more nutritious food in less time and space, compared to wheat and rice plants, which are the most produced crops in the world (Dale and Mackay 1994; Fao, 2016). This makes potato plants highly demanding of the presence of readily available nutrients in the soil solution. Thus, in intensive potato growing systems, high amounts of phosphate fertilizers and other fertilizers are normally used, which reduces the sustainability of the crop (Silva et al., 2014).

The nutritional efficiency of $P$ has been defined based on the process by which plants acquire, transport, store and use the nutrient in order to produce biomass (Parentoni and Souza, 2008). The high performance in $P$ limiting conditions is due to the greater capacity of some genotypes to acquire $P$ from the environment and / or to a greater capacity to use $P$ internally (Pinto et al., 2011). Therefore, exploring the genetic, physiological and biochemical characteristics of plants in order to select potato clones that are more efficient for $P$ and, thus, developing agricultural systems that can produce more with limited availability of $P$ will be necessary to meet the food production challenge (DoVale et al., 2013). The objective of this study was to evaluate the performance of four potato clones regarding the nutritional efficiency of $P$ in closed off-soil growing system using native soil as a substrate.

\section{Results and discussion}

The concentration of $P$ in the tissues of the plant can be a good indicator of the nutritional status in which it is found, since plants in a condition of $\mathrm{P}$ limitation increase the 
redistribution of $\mathrm{P}$ from the shoot to the roots (Machado et al., 2001; Mollier and Pellerin, 1999). The Asterix and Atlantic clones showed a reduction of 13 and $33 \%$ in the concentration of $P$ in the shoot when grown under low level of $P$, due to greater internal remobilization of $P$ to the roots or poor absorption of $\mathrm{P}$ from the substrate when it was less available. However, clones SMIC 148-A and SMINIA 7931013 showed no difference in the concentration of $P$ in the shoot due to the levels of $P$ tested (Table 1 ), which may be an indication that these clones are less sensitive to the condition of $P$ restriction. The SMIC 148-A was the most efficient clone for concentrating a greater amount of $\mathrm{P}$ in the shoot both at the low $\left(10.2 \mathrm{mgP}_{\mathrm{gDM}}{ }^{-1}\right)$ and at the high

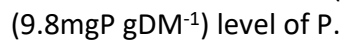

The cycled $P$ fraction resulting from the greater retention of $P$ in the roots and redistribution via phloem, which brings additional $P$ to them under the condition of $P$ deficiency, can alter the drain force from the photosynthesized to the roots at the expense of the shoot, reducing the shoot growth (Wissuwa et al., 2005). In this study, it was observed for the four clones, a reduction in the production of shoot dry matter (DM) when grown under low level of $P$, this reduction being 34, 21, 34 and 29\% respectively for the Asterix, Atlantic, SMIC 148-A and SMINIA 793101-3 clones (Table 1). This reduction in the shoot DM under low level of $P$ consequently compromised the production of total DM of the clones, this reduction was of 36, 42, 23 and 38\% in the total DM respectively for Asterix, Atalntic, SMIC 148-A and SMINIA 793101-3, (Table 1). Asterix was the most efficient clone in the production of shoot DM at the low level of $P$ $\left(7.88 \mathrm{~g} \mathrm{pl}^{-1}\right)$ and the one that best responded to the increase in $\mathrm{P}$, producing at the high level $11.94 \mathrm{~g} \mathrm{pl}^{-1}$ (Table 1 ). With regard to total DM, clone SMIC 148-A was the most efficient in the production of biomass under low level of $P\left(11.55 \mathrm{~g} \mathrm{pl}^{-}\right.$ $\left.{ }^{1}\right)$, without differing from Asterix and SMINIA 793101-3 at high level (Table 1).

For all potato clones in the present study, the rooting efficiency for $P$ (REP) was very low, regardless of the level of $P$ (Table 1). A good initial development of the root system, which occupies a large volume of soil, could facilitate the acquisition of phosphorus (P) and compensate for the inefficient absorption of this nutrient by potato plants, since this nutrient is not very mobile in the soil (Alvarado et al., 2009). However, only the SMINIA 793101-3 clone showed a difference between the $P$ levels, with lower rooting efficiency at a low $P$ level $\left(0.05 g^{2}\right.$ dry root mass $\mathrm{mg}^{-1} \mathrm{P}$ in the shoot). This low rooting efficiency can compromise the development of plants, so that it does not occur, it is necessary to make use of high levels of phosphate fertilizer applied in a localized manner so that it does not affect the metabolism and the production of the plant. The Atlantic clone had the lowest REP at both levels, without differing from SMINIA 793101-3 at the lowest level of P.

The absorption of $P$ by the roots is the result of the interaction of the morphological and physiological characteristics of the potato plants with the rhizosphere and the soil around the root system, which are the factors that determine the flow of nutrients at the soil-root interface (Alves et al., 2002). The Asterix, Atlantic and SMIC 148-A clones showed a reduction in the $P$ absortion efficiency (PAE), respectively, of 27,42 and $12 \%$ when grown at a low level of $P$ (Table 1). As the EEP is naturally low for the potato clones tested, the high PAE at the high level of $P$ seems to have occurred due to the increase in the level of applied nutrient and not due to the greater exploitation of the soil by the roots, reinforcing once again the need to improve the tools that can assist in the distribution of fertilizers based on soil and crop variability, optimizing production, minimizing over-application or under-application of nutrients (Phillips, 2014). Among the clones, in the low level of $P$, SMINIA $793101-3$ (81.1 $\mathrm{mg} \mathrm{g}^{-1}$ ) was the most efficient in the absorption of $P$. In high level of $P$, Atlantic $\left(110.9 \mathrm{mg} \mathrm{g}^{-1}\right)$ was the one that most absorbed $P$ from the soil.

In order to efficiently acquire and distribute $P$, in a condition of $P$ limitation, the transport of the nutrient in the plant's organs must be coordinated by carrier proteins, which includes the processes of absorption of $P$ from the soil by the roots, the translocation to shoot and the redistribution between plant organs (Ibara and Miwa, 2014). A possible change to be observed in plants in a condition of $\mathrm{P}$ limitation is the induction of high affinity nucleases and $\mathrm{Pi}$ transporters, which is directly related to the total $\mathrm{P}$ content in the plant (Ticconi et al., 2004). The P translocation efficiency (PTE) from the roots to the shoot in the Asterix clone did not differ between the $P$ levels (Table 1). However, PTE was lower for clone SMIC 148-A (11.5\%) and higher for clones Atlantic (9.6\%) and SMINIA 793101-3 (19\%) under low $P$. These results show the variability of PTE between these clones and this difference can be exploited positively by potato breeding programs.

One of the ways to reduce the amount of fertilizer applied to the potato crop is by choosing cultivars that make better use of nutrients (Fernandes and Soratto, 2013). Although there was no interaction between the levels of $P$ and the potato clones tested regarding the $P$ utilization efficiency (PUE), it was observed that the Asterix and Atlantic clones showed greater capacity to convert the absorbed $P$ into biomass and the SMIC 148-A was the one with the lowest PUE (Table 1). These results allow the adoption of different fertilization regimes in the potato crop, with smaller applications of fertilizers in the planting of cultivars efficient in P utilization. Although, for the clones tested in this study, the highest PUE occurred at the high level of $P$. This finding was surprising because other studies have shown that the higher the $P$ content available to plants, the lower the $\mathrm{P}$ utilization efficiency (Gondim et al., 2010).

\section{Materials and methods}

\section{Local and plant materials}

The experiment was conducted in a greenhouse with partially controlled temperature, maintained at $25 \pm 3 \circ \mathrm{C}$,

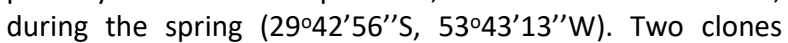
SMIC 148-A and SMINIA 793101-3 from the Potato Genetics and Breeding Program at the Federal University of Santa Maria - UFSM and two Asterix and Atlantic cultivars were used, which for the purposes of simplification will be referred to in this study as clones.

\section{Conduction of study and experimental design}

For the experiment, $5 \mathrm{~L}$ plastic pots $(20 \mathrm{~cm}$ in diameter and $20 \mathrm{~cm}$ in height) were used, which contained $4 \mathrm{~kg}$ of native soil (Umbric Alkyd Bruno-Gray Argisol (Ultisol), Embrapa, 2013) from a native field. The main attributes of the soil are: $18 \%$ clay; $25 \mathrm{~g} \mathrm{~kg}^{-1}$ organic matter; $\mathrm{pH}$ (water $1: 1$ ) of $4.6 ; 30.6 \%$ $\mathrm{Al}$; $26.5 \%$ base saturation; $6.2 \mathrm{cmol}_{c} \mathrm{dm}^{-3}$ of effective CEC; $2.8 \mathrm{cmol}_{\mathrm{c}} \mathrm{dm}^{-3} \mathrm{Ca}, 1.4 \mathrm{cmol}_{\mathrm{c}} \mathrm{dm}^{-3} \mathrm{Mg}, 3 \mathrm{mg} \mathrm{kg}^{-1} \mathrm{P}$ (Mehlich-1) and $76 \mathrm{mg} \mathrm{kg}^{-1} \mathrm{~K}$ (Mehlich-1). Liming was carried out by incorporating calcium hydroxide together with magnesium oxide (a preliminary test was carried out to show the 
Table 1. Effect of $P$ level on rooting, absorption, translocation and utilization efficiency in potato clones evaluated at 52 days after planting in closed growing system using soil as substrate. Santa Maria, RS, 2017.

\begin{tabular}{|c|c|c|c|c|c|c|c|c|c|}
\hline P level & Asterix & \multicolumn{3}{|c|}{ Atlantic } & \multicolumn{2}{|c|}{ SMIC 148-A } & \multicolumn{2}{|c|}{ SMINIA 793103-3 } & \multirow[t]{2}{*}{ Average } \\
\hline \multicolumn{9}{|c|}{$\mathrm{P}$ concentration in the shoot dry mass $\left(\mathrm{mgP} \mathrm{gMS}^{-1}\right)$} & \\
\hline High & 4.19 & Ac & 4.26 & Ac & 9.77 & Aa & 8.76 & $A b$ & 6.75 \\
\hline Low & 3.65 & $\mathrm{Bc}$ & 2.87 & $\mathrm{Bd}$ & 10.16 & $\mathrm{Aa}$ & 8.72 & $\mathrm{Ab}$ & 6.35 \\
\hline Average & 3.92 & & 3.56 & & 9.97 & & 8.74 & & \\
\hline CV (\%) & 3.82 & & & & & & & & \\
\hline \multicolumn{10}{|c|}{ Shoot dry mass $\left(\mathrm{g} \mathrm{pl}^{-1}\right)$} \\
\hline High & 11.94 & $\mathrm{Aa}$ & 6.19 & Ac & 8.91 & $\mathrm{Ab}$ & 9.23 & $A b$ & 9.07 \\
\hline Low & 7.88 & $\mathrm{Ba}$ & 4.89 & $\mathrm{Bc}$ & 5.84 & $\mathrm{Bc}$ & 6.55 & $\mathrm{Bb}$ & 6.29 \\
\hline Average & 9.91 & & 5.54 & & 7.37 & & 7.89 & & \\
\hline CV (\%) & 7.52 & & & & & & & & \\
\hline \multicolumn{10}{|c|}{ Total dry mass $\left(\mathrm{g} \mathrm{pl}^{-1}\right)$} \\
\hline High & 15.44 & $A b$ & 14.10 & $A b$ & 15.09 & $\mathrm{Aa}$ & 17.23 & $A b$ & 15.47 \\
\hline Low & 9.81 & $\mathrm{Ba}$ & 8.15 & $\mathrm{Bb}$ & 11.55 & $\mathrm{Ba}$ & 10.61 & $\mathrm{Ba}$ & 10.03 \\
\hline Average & 12.63 & & 11.13 & & 13.32 & & 13.92 & & \\
\hline CV (\%) & 6.87 & & & & & & & & \\
\hline \multicolumn{10}{|c|}{ Rooting efficiency for $P(R E P)\left(g^{2} \mathrm{mg}^{-1}\right)$} \\
\hline High & 0.11 & $\mathrm{Aa}$ & 0.04 & $\mathrm{Ab}$ & 0.09 & $\mathrm{Aa}$ & 0.10 & $\mathrm{Aa}$ & 0.09 \\
\hline Low & 0.11 & $\mathrm{Aa}$ & 0.05 & $A b$ & 0.10 & $\mathrm{Aa}$ & 0.05 & $\mathrm{Bb}$ & 0.08 \\
\hline Average & 0.11 & & 0.05 & & 0.09 & & 0.08 & & \\
\hline CV (\%) & 13.78 & & & & & & & & \\
\hline \multicolumn{10}{|c|}{ P absorption efficiency (PAE) $\left(\mathrm{mg} \mathrm{g}^{-1}\right)$} \\
\hline High & 59.79 & Ac & 110.87 & $\mathrm{Aa}$ & 82.33 & $A b$ & 79.29 & $A b$ & 83.07 \\
\hline Low & 43.58 & $\mathrm{Bd}$ & 63.90 & $\mathrm{Bc}$ & 72.70 & $\mathrm{Bb}$ & 81.10 & $\mathrm{Aa}$ & 65.32 \\
\hline Average & 51.69 & & 87.39 & & 77.51 & & 80.20 & & \\
\hline CV (\%) & 5.99 & & & & & & & & \\
\hline \multicolumn{10}{|c|}{$\mathrm{P}$ translocation efficiency (PTE) } \\
\hline High & 35.97 & $A b$ & 22.89 & $\mathrm{Bc}$ & 38.10 & $\mathrm{Aa}$ & 35.69 & $\mathrm{Bb}$ & 33.16 \\
\hline Low & 37.90 & $A b$ & 25.09 & $\mathrm{Ad}$ & 33.70 & $\mathrm{Bc}$ & 42.50 & $\mathrm{Aa}$ & 34.80 \\
\hline Average & 36.94 & & 23.99 & & 35.90 & & 39.10 & & \\
\hline CV (\%) & 3.30 & & & & & & & & \\
\hline \multicolumn{10}{|c|}{ P utilization efficiency (PUE) $\left(\mathrm{g}^{2} \mathrm{mg}^{-1}\right)$} \\
\hline High & 1.72 & & 1.74 & & 1.00 & & 1.31 & & $1.44 \mathrm{~A}$ \\
\hline Low & 1.27 & & 1.19 & & 0.76 & & 0.84 & & $1.02 \mathrm{~B}$ \\
\hline Average & 1.49 & $\mathrm{a}$ & 1.46 & $\mathrm{a}$ & 0.88 & c & 1.07 & $\mathrm{~b}$ & \\
\hline CV (\%) & 10.70 & & & & & & & & \\
\hline
\end{tabular}

effectiveness of this procedure). Three days after liming, urea and potassium chloride were applied as recommended for potato growing (Manual of fertilization and liming for the states of Rio Grande do Sul and Santa Catarina, 2004) and then the tubers were planted, one by vase.

At the time of planting (10/6/14), the tubers used had an average weight of $37,32,26$ and $28 \mathrm{~g}$ respectively for the Asterix, Atlantic, SMIC 148-A and SMINIA 793101-3 clones. The $P$ levels used were 0.025 and $0.11 \mathrm{~g} \mathrm{Kg}^{-1}$ of potassium monophosphate ( $\mathrm{KH} 2 \mathrm{PO} 4)$ equivalent levels respectively to 35 and $140 \mathrm{~kg}$ ha-1 of P2O5, referred to in this study as low and high levels of P. Potassium monophosphate was dissolved in water and incorporated into the soil ten days after planting the tubers. The irrigation was done manually, as necessary to maintain the soil with $70 \%$ of the field capacity. The experimental design was completely randomized, in a $2 \times 4$ factorial (two levels of $P$ and four clones) with three replications.

\section{Characteristics measured}

At 52 days after planting, at the beginning of tuberization according to Heldwein et al. (2009), the plants were harvested, washed under running water and divided into shoots, tubers and roots. For each treatment, the dry mass (DM) of the shoot, tubers and roots was evaluated. The DM was determined after drying the material for 15 days in an oven with forced air circulation at $60^{\circ} \mathrm{C}$. The analysis of the total $\mathrm{P}$ concentration in the tissues was performed according to Tedesco et al. (1995), with the digestion of $0.2 \mathrm{~g}$ of tissue with $0.7 \mathrm{~g}$ of digestion mixture (100g of $\mathrm{Na}_{2} \mathrm{SO}_{4}, 10 \mathrm{~g}$ of CuSO $\mathrm{S}_{4} .5 \mathrm{H}_{2} \mathrm{O}$ and $1 \mathrm{~g}$ of selenium) in sulfuric acid $\left(\mathrm{H}_{2} \mathrm{SO}_{4}\right)$ with hydrogen peroxide $\left(\mathrm{H}_{2} \mathrm{O}_{2}\right)$ remaining in a digestion block for one hour at $350 \stackrel{\circ}{ } \mathrm{C}$. The determination of $\mathrm{P}$ in plant tissue extracts was performed by colorimetry, according to Murphy and Riley (1962).

The accumulation of $P$ in the tissues was obtained by the product between the concentration of $P$ and the $D M$ of each organ of the plant. Once these data were obtained, the following efficiency indexes were estimated for $P$ : i) rooting efficiency for $P$ (REP): (root $D M)^{2} / P$ accumulation in the shoot, according to Siddiqi and Glass (1981); ii) P absorption efficiency (PAE): accumulation of $P$ in the plant/root DM, according to Swiader et al. (1994); iii) $P$ translocation efficiency (PTE): accumulation of $P$ in the 
shoot/accumulation of total P, according to Li et al. (1991); and iv) $P$ utilization efficiency (PUE): (total plant $D M)^{2} / P$ accumulation in the entire plant, according to Siddiqi and Glass (1981).

\section{Statistical analysis}

The data were submitted to analysis of variance and the means between clones and between levels of $P$ were compared by the Skott-Knott test (Scott and Knott, 1974) at a $5 \%$ probability of error, with the help of the Sisvar 5.3 Software (Ferreira, 2011).

\section{Conclusion}

SMIC 148-A is the clone that most concentrates $P$ in the shoot and that produces the most total dry mass under low $P$, while SMINIA 793101-3 is the most efficient clone in the absorption and translocation of $\mathrm{P}$ under low nutrient level. However, Asterix and Atlantic clones showed the greatest $P$ utilization efficiency.

\section{Acknowledgements}

We thank the Coordenação de aperfeiçoamento de pessoal de nível superior (CAPES) for research productivity scholarship for first author, and to the Potato Breeding Program at UFSM for granting genotypes.

\section{References}

Alvarado A, Iturriaga I, Smyth JT, Ureña JM, Portuguez E (2009) Efecto de la fertilización con fósforo sobre el rendimento y la absorción de nutrintos de la papa en un andisol de Juan Viñas, Costa Rica. Rev Agron Costarricense. 33:45-61.

Alves VMC, Parentoni SN, Vasconcellos CA, Pitta GVE, França CCM (2002) Cinética de absorção e crescimento do sistema radicular de genótipos de milho contrastantes para eficiência a fósforo. Rev Bras de Milho e Sorgo. 1:85-92.

Dale MFB, Mackay GR (1994) Inheritance of table and processing quality. In: Bradshaw, J.E.; Mackay, G.R. (ed). Potato Genetics, 285-315.

DoVale JC, Maia C, Fritsche-Neto R, Miranda GV, Cavatte PC (2013) Genetic responses of traits relationship to components of nitrogen and phosphorus use efficiency in maize. Acta Scien. 35:31-38.

Empresa brasileira de pesquisa agropecuária - Embrapa (2013) Sistema brasileiro de classificação de solos. 2ed Rio de Janeiro.

Fernandes AM, Soratto RP (2013) Eficiência de utilização de nutrientes por cultivares de batata. Biosci J. 29:91-100.

Ferreira DF (2011) Sisvar: a computer statistical analysis system. Ciênc e Agrotec. 35:1039-1042.

Food and agriculture organization - Fao. FAOSTAT (2016) Produção mundial de batata.

Godfray HCJ, Beddington JR, Crute IR, Haddad L, Lawrence D, Muir FJ, Pretty J, Robinson S, Thomas SM, Toulmin C (2010) Food Security: The Challenge of Feeding 9 Billion People. Science. 327:812-818.

Gondim ARO, Prado RM, Alves AU, Fonseca IM (2010) Eficiência nutricional do milho cv. BRS 1030 submetido à omissão de macronutrientes em solução nutritiva. Rev Ceres. 57:539-544.
Heldwein AB, Streck NA, Bisognin DA (2009) Batata. In: Monteiro JEBA (ed.). Agrometeorologia dos cultivos: o fator meteorológico na produção agrícola. Brasília. Inst Nac de Met. 91-109.

Ibara I, Miwa K (2014) Strategies for optimization of mineral nutrient transport in plants: multi-level regulation of nutrient-dependent dynamics of root architecture and transporter activity. Plant Cell Phys. 55:2027-2036.

Li B, McKeand SE, Allen HL (1991) Genetic variation in nitrogen use efficiency of loblolly pine seedlings. Forest Scie. 37:613626.

Machado CTT, Furlani AC, Machado AT (2001) Índices de eficiência de variedades locais de melhoradas de milho ao fósforo. Rev Bragantia. 60:225-238.

Mollier A, Pellerin S (1999) Maize root system growth and development as influenced by phosphorus deficiency. J Exp Botany. 50:487-497.

Murphy J, Riley JP (1962) A modified single solution method for the determination of phosphate in natural waters. Analy Chimica Acta. 27:31-36.

Parentoni SN, Souza CLr (2008) Phosphorus acquisition and internal utilization efficiency in tropical maize genotypes. Pesq Agropec Bras. 43:893-901.

Phillips S (2014) Indústria de fertilizantes e agricultura de precisão: apoio à segurança alimentar mundial. Infor Agronômicas. 146.

Pinto SIC, Furtini Neto AE, Neves JCL, Faquin V, Moretti BS (2011) Eficiência nutricional de clones de eucalipto na fase de mudas cultivados em solução nutritiva. $\mathrm{R}$ Bras Ci Solo. 35:523-533.

Rhoads RE (2003) A batata excelente. In: Pereira AS, Daniels J (Ed) O cultivo da batata na região sul do Brasil. Brasília: Embrapa Informação Tecnológica. 53-143.

Scott AJ, Knott M (1974) A cluster analysis method for grouping means in the analysis of variance. Biometrics. 30:507-512.

Siddiqi MY, Glass ADM (1981) Utilization index: a modified approach to the estimation and comparison of nutrient efficiency in plants. J Plant Nutrition. 4:289-302.

Silva GO, Pereira AS, Suinaga FA, Carvalho ADF (2014) Rendimento de tubérculos de clones elite de batata. Hortic Bras. 32:230-233.

Soil chemistry and fertility commission - RS/SC. (2004) Manual of fertilization and liming for the states of Rio Grande do Sul and Santa Catarina. 10 ed. Porto Alegre.

Swiader JM, Chyan Y, Freiji FG (1994) Genotypic differences in nitrate uptake and utilization efficiency in pumpkin hybrids. J Plant Nutrition. 17:1687-1699.

Tedesco MJ, Gianello C, Bissani CA, Bohnen H, Volkweiss SJ (1995) Análise de solo, plantas e outros materiais. 2 ed. Porto Alegre.

Tester M, Langridge P (2010) Breeding technologies to increase crop production in a changing world. Science. 327:818-822.

Ticconi CA, Delatorre CA, Lahner B, Salt DE, Abel S (2004) Arabidopsis pdr2 reveals a phosphate-sensitive checkpoint in root development. Plant J. 37:801-814.

Wissuwa M, Gamat G, Ismail AM (2005) Is root growth under phosphorus deficiency affected by source or sink limitations? J Exp Bot. 56:1943-1950. 